\title{
A EXCLUSÃO SOCIAL VISTA PELA IMPRENSA
}

\author{
(Social exclusion as seen by the press)
}

\begin{abstract}
Theresa Christina Jardim Frazão ${ }^{1}$ (Universidade de Brasília-UnB/Universidade de Pernambuco - UPE)
\end{abstract}

\begin{abstract}
This work aims to identify how journalistic discourse and reader feedback can serve as empirical sources for a theoretical-methodological approach to questions of language valuation. The Critical Discourse Analysis (CDA) and Systemic Functional Linguistics approaches subsidize this field of research, which finds support, in the special case of microanalysis, in the interpersonal metafunction and in the analytical model of Appraisal Systems. The facts narrated by the print media about the homeless, human beings who live in conditions of deprivation and poverty, are almost completely restricted to the police pages, where they lose their ontological essence.
\end{abstract}

Keywords: discourse; journalism; value system; social practices.

\section{RESUMO}

Este trabalho tem o objetivo de identificar como o discurso jornalístico e o feedback do leitor podem ser fontes empíricas para uma aproximação teóricometodológica a questões de valoração na linguagem. A Análise do Discurso Crítica e a Linguística Sistêmico-Funcional subsidiam esse campo de pesquisa, que encontra respaldo, em termos de microanálise, na metafunção interpessoal, e no modelo analítico de Valoração* (Appraisal Systems). Os fatos narrados pela imprensa sobre as pessoas que vivem nas ruas, em situação de precariedade

1 É professora da Universidade de Pernambuco - UPE e doutoranda em Linguística na Universidade de Brasília, UnB. Graduada em Letras e em Jornalismo, é mestre em Ciências da Linguagem. Na linha da análise crítica do discurso publicou o livro Sistema de cotas e o discurso da imprensa. Atualmente pesquisa a produção jornalística sobre moradores de rua de grandes centros urbanos. 
e penúria, estão restritos quase somente às páginas policiais, onde elas perdem a essência ontológica.

Palavras-chave: discurso; jornalismo; sistema valorativo; práticas sociais.

\section{Introdução}

Neste artigo apresento uma amostra do discurso midiático sobre o tratamento dispensado aos excluídos da nossa sociedade, o que pode resultar em comentários feitos por leitores, constituindo um novo discurso, desta feita com linguagem mais contundente e marcada por disfemismos. O objetivo é identificar como o discurso jornalístico e o feedback do leitor podem ser fontes empíricas para uma aproximação teórico-metodológica a questões de valoração na linguagem. Julgo importante proceder à análise das matérias jornalísticas, bem como de cartas publicadas em jornais, no caso específico sobre o morador de rua, por permitir a identificação do grau de valorização e preservação da sua identidade, como da condição de sujeito do seu mundo, ou se, ao contrário, há a sua invisibilidade, visto que ele está posto na base na escala social, sem papel definido e assunção da sua cidadania.

O morador de rua, o sem teto é aquele que vive em situação de pobreza extrema, que tem os vínculos familiares interrompidos ou fragilizados e que não tem moradia. Mas, sempre é aquele que incomoda, basta observar o que a imprensa publica e, com mais rigor, o que os leitores fornecem como feedback sobre o que lêem e sobre a sua experiência com aquelas pessoas que se espalham pelos centros urbanos. Ao se referir à pobreza nas ruas, Silva (2008:272) afirma que a exclusão social constitui a resultante dentro de um continuum formado por uma série de rupturas de vínculos sociais, familiares e individuais, alguns deles, frequentemente, sem condições de recuperação.

Os moradores de rua, alijado da economia formal, recolhem o que é descartado pela sociedade de consumo, o que é posto de lado. E antes que cheguem os caminhões da limpeza pública para levá-lo, não importa 
para onde, aparece a pobre gente a vasculhá-lo. Quem olha de fora, tende a associar o ser humano com esse lixo. E a análise do signo linguístico demonstra o estigma que cerca a atividade, pois lixo é o que se joga fora, é entulho. É tudo que, por não prestar, é descartado. É sujeira, refugo, sujidade, imundície, constituída de coisas inúteis, sem nenhum valor. E quem recolhe e usa esse lixo tem essas conotações aderidas a si mesmo como se fora uma segunda pele.

Busco, então, observar, de acordo com Fairclough (2001), a relação dialética entre discurso e estrutura social para evitar erros de ênfase indevida, tanto na determinação social do discurso como na construção social no discurso. O discurso é fruto da criação do homem, da intenção de construção de valores, de sentidos, de ideais e de representações das experiências possibilitadas pelo agir social. São os participantes da cultura que dão significados às pessoas, objetos e eventos: "O significado resulta da nossa vivência com as coisas, com o que dizemos, pensamos e sentimos sobre elas. É pela maneira como as representamos que damos sentidos às coisas."(HALL, 2000, p. 3).

\section{Pressupostos teóricos}

A perspectiva dialética considera a prática e o evento contrapostos e em luta, com uma relação complexa e variável com as estruturas, às quais manifestam apenas uma fixidez temporária, parcial e contraditória. É em um contexto específico que está o sujeito pensado por Foucault (1986, p.207), executor das práticas discursivas: "não há saber sem uma prática discursiva definida, e toda prática discursiva pode definir-se pelo saber que ela forma”. Essas práticas são provenientes da conjunção do discurso, sociedade e história, o que pode provocar a mudança dos saberes e, consequentemente, a articulação com os poderes. $\mathrm{O}$ discurso é socialmente constitutivo porque contribui para a configuração das dimensões da estrutura social que, direta ou indiretamente, o moldam e o restringem. É uma prática não apenas de representação do mundo, 
mas de sua significação, constituindo e construindo esse mundo em significados.

Van Dijk (2008:52), ao estabelecer a relação discurso e poder, identifica com isto acontece e a importância da sua observância nas formas de reprodução e disseminação do discurso do poder: "Os falantes costumam ter um papel institucional e seus discursos apóiamse com frequência no poder institucional. Nesse caso, consegue-se a aquiescência muitas vezes através das sanções legais ou de outros tipos de sanção institucional.” O discurso materializa as práticas sociais de produção de textos. Portanto, todo discurso é uma construção social, não individual, e somente pode ser analisado ao se considerar o seu contexto histórico-social. O discurso reflete uma visão de mundo determinada, necessariamente vinculada à dos seus autores e à sociedade em que vivem.

A Análise do Discurso Crítica (ADC) é um percurso interdisciplinar para o estudo dos textos que considera a "linguagem como uma forma de prática social.” (FAIRCLOUGH, 2001). É indispensável à proposta da presente pesquisa porque permite o acesso a um suporte científico para questionamentos de problemas sociais relativos a poder e justiça, o que é característico da sua natureza de "ciência social crítica." (FAIRCLOUGH, 2003). É assim que pretende desvelar os fundamentos ideológicos do discurso que, ao assumirem apresentação tão natural ao longo do tempo, são vistos como comuns, aceitáveis e como traços naturais da composição.

As representações sociais são visíveis e caracterizadas pela hierarquização dos papéis: há os detentores do poder e os que lhes são subordinados, a constituir massa inerte e desejavelmente passiva, submetida ao rigor da lei e do medo. Van Leeuwen (1997, p. 187) argumenta que "representações podem dotar os atores, quer com papéis ativos quer com papéis passivos. A ativação ocorre quando os atores sociais são representados como forças ativas e dinâmicas numa atividade, e a passivação quando são representados como 'submetendose' à atividade, ou como sendo receptores dela. 
Para corroborar a ADC, a Linguística Sistêmico-Funcional é excelente caminho para a análise dos dados linguísticos sinalizadores. Segundo o próprio Halliday (1994, p.14), a LSF é uma teoria do significado como escolha, através da qual a língua, ou outro sistema semiótico, tem a sua interpretação baseada em uma rede de opções múltiplas: ou esta, ou aquela, ou a outra, ou mais como uma ou mais como a outra etc. Para explicar a linguagem, deve-se começar com os traços mais gerais até chegar ao procedimento mais específico, pois "uma mensagem é ou sobre fazer ou sobre pensar, ou sobre ser."

Fairclough (2003, p. 98) ao dividir a troca de informação em "troca de conhecimentos" e em "troca de atividades," que acontecem por meio da disposição gramatical (orações declarativas, interrogativas ou imperativas), mostra que essa disposição se expressa nos atos de fala do entrevistador e entrevistado, que tendem a usar mais questões declarativas do que as interrogativas, na busca da expressão do que cada um quer dizer. Dessa forma, ambos buscam estratégias de legitimação.

Então, Fairclough na mesma obra, baseando-se em van Leeuwen (1999), divide essas estratégias em: 1-Autorização, que é a legitimação em referência à autoridade ou tradição, costume, lei ou o papel institucional de alguém que o faz uma autoridade. 2- Racionalização, legitimação relativa aos serviços de uma ação institucionalizada e aos conhecimentos que a sociedade vem construindo e aos quais agrega validade cognitiva. 3- Avaliação moral, compreendendo a legitimação referente ao sistema de valores. 4- Mitopoese ${ }^{2}$ (mythopoesis), a significar a criação de lenda e mitos na busca da possibilidade de legitimação através da narrativa.

Outro referencial que julgo da maior importância é o Sistema da Valoração (Appraisal Systems) a partir dos estudos de Peter White (2004) e J. R. Martin (2003), Martin e White (2005), Martin e Rose

2 Of or relating to the making of myths. Serving to create or engender myths; productive in mythmaking. ( FAIRCLOUGH, 2003,p.98) 
(2002),(2008), desde que: “...o modelo oferece uma abordagem que permite explorar as formas como a voz textual se posiciona em relação a essas avaliações, numa aproximação que enseja caracterizar as diferentes perspectivas intersubjetivas disponíveis para a voz textual.” (WHITE, 2004, p.177).

Para uma melhor visualização e aplicação da teoria desses autores (MARTIN E WHITE, 2005), proponho o esquema:

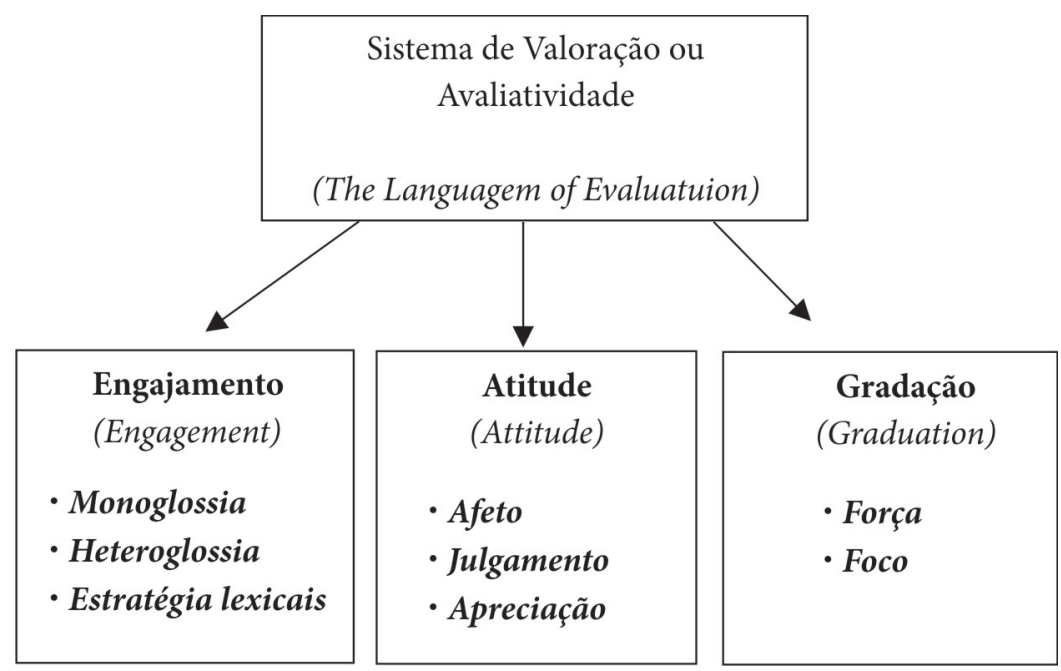

Ao uso desse parâmetro de análise, é importante agregar a contribuição de Thompson (2009, p.81-89) sobre os modos de operação da ideologia, que se realiza através de algumas estratégias típicas de construção simbólica, como:

- Legitimação (racionalização; universalização e narrativização).

- Dissimulação (deslocamento; eufemização; tropo).

- Reificação (naturalização; eternalização; nominalização/ passivação).

Para o autor, "o estudo da ideologia exige que investiguemos as maneiras como o sentido é construído e usado pelas formas simbólicas 
de vários tipos, desde as falas linguísticas cotidianas até às imagens e aos textos complexos." (ibid. p.16).

\section{Metodologia}

Apresento neste artigo um exemplo, que faz parte de um corpus mais amplo, de uma pesquisa em desenvolvimento, constituído de textos jornalísticos publicados em grandes jornais do País e nas respostas (feedbacks) dos leitores sobre o tema da pesquisa. Uso, tanto os textos que aparecem nos jornais impressos, na seção "cartas do leitor”, quanto os que são divulgados em sites das empresas jornalísticas, que disponibilizam espaço para manifestações sobre os temas selecionados pelo emissor da notícia, inclusive com a ilustração de fotos da autoria do mesmo. Destaco a intenção desse redator que se apropria da linguagem do repórter e tenta se adequar ao veículo midiático. Um exemplo dessa prática é o do jornal "O Globo" (on line) com o seu "Eu-Repórter."

O leitor que se interesse pode transformar-se, dessa forma, em um novo jornalista (antes mesmo de ser legalmente desobrigado de possuir o diploma de Comunicação Social). Para tanto, basta ter acesso a um computador, querer transmitir uma mensagem e passar a relatar um fato de sua escolha, portanto, por ele mesmo pautado, e ao qual mistura a sua opinião, mesclando os dois subgêneros jornalísticos (informativo e opinativo), o que resulta, muitas vezes, em um texto com grande ferocidade e virulência linguística, onde são perceptíveis modos de operação da ideologia, como a dissimulação e a reificação, de acordo com a classificação de Thompson (2009, p.81-89).

Van Dijk (2000, p. 55) analisa a questão da tomada de decisão sobre o que é notícia, já que é a proximidade que permite ao jornalismo perceber os contextos que determinam os valores-notícia e, consequentemente, organizar os restantes dos elementos valorativos, como a novidade, a atualidade, a relevância, a consonância, o desvio 
e a negatividade. Inegavelmente, tudo que se consubstancia no exercício do poder a partir da identificação do que é notícia sob a ótica do seu produtor. Por sua vez, Pardo (2007, p.25) ressalta que a imprensa, como meio de comunicação, recupera todas as expressões possíveis do dizer em relação aos problemas e assuntos próprios de uma comunidade e que, ao se reconhecer a validade do procedimento, é possível identificar as diversas organizações do significado.

Entre as três metafunções da LSF, particularizo, no caso presente, a Função Interpessoal que me permite realizar a análise pretendida, pois, segundo Halliday (1994, p.68), ao mesmo tempo em que se organiza a mensagem, a oração também é organizada como evento interativo composto por um falante, ou escritor, e seu(s) ouvinte(s). Explica que o termo 'falante' é usado de forma ampla, de modo a ter aplicação tanto na conversação como na expressão escrita, mas, sem dúvida, a constituir um ato de fala. É, então, esse falante que assume para si determinado papel discursivo, ou atuação discursiva ( (speech role), deixando ao ouvinte um papel complementar, que vejo, na dinâmica da interação midiática, como mais secundário.

O uso do Sistema de Valoração (Appraisal Systems) está circunscrito à aplicação de pressupostos de Martin (2003), White (2004), Martin \& White (2005) e Martin e Rose (2002),(2008) aos textos estudados, no que se refere especificamente ao Subsistema de Atitudes, com seus critérios tipológicos de afeto, julgamento e apreciação. Esses aspectos se referem particularmente à maneira como os emissores se posicionam nos textos que elaboram, como são realizadas, linguisticamente, campos de envolvimento, de atitudes, a significar aprovação, desaprovação, entusiasmo ou rejeição em referência aos significados que transmitem, além de antever o modo como os falantes constroem suas identidades nos textos, perpassados por ideologias claramente expostas ou pretensamente ocultada. 


\section{Análise de nota de coluna}

\section{Dilemas humanos}

Fernando Willian, secretário de ação social do Rio, está surpreso com alguns moradores da Praça Seca, em Jacarepaguá, contrários à construção de um asilo no lugar:

- As pessoas querem que sejam construídos abrigos para recolher moradores de rua. Mas bem longe delas.

É. Pode ser.

(O GLOBO, Rio de Janeiro, quinta-feira, 4 de junho de 2009. Coluna ANCELMO GOIS / p. 20).

A nota foi publicada no primeiro caderno do jornal impresso $O$ Globo, na editoria RIO, na coluna ANCELMO GOIS que se propõe a veicular "Notas exclusivas sobre o Rio, o Brasil e o mundo, em tempo real". Os assuntos tratados são: "Política, comportamento, moda e cultura carioca.” A coluna em questão ocupa, de acordo com a hierarquia de importância patética, definida pelo jornal $O$ Globo, uma posição que ultrapassa a classificação média, tanto em relação ao caderno quanto à página (primeiro caderno, meia página, lado esquerdo, posição superior).

Van Dijk (2003, p. 46) faz uma revisão sobre o papel da ideologia das notícias, desde que ela "não somente se limita ao conteúdo e ao estilo, mas também inclui a captação dessas notícias, as fontes de informação, a interação entre jornalistas e novos atores sociais e a organização das atividades profissionais". O autor lembra o que a prática confirma: "as ideologias profissionais e sociais dos jornalistas controlam a quem se investigará, cobrirá, escutará ou entrevistará.”

Subjacente, está a ideia de que essas mesmas ideologias profissionais também controlam o que se escreverá, ou se omitirá, nas notícias, no apelo das manchetes e titulações, sempre com 
a observância das regras e exigências do gênero jornalístico. Isso pode ser constatado a partir do título escolhido por Alcelmo Gois - DILEMAS HUMANOS - tendo como chamamento a questão existencial que remete à dúvida shakespeariana do "ser ou não ser", consubstanciada na carga semântica de mais um dentre os dilemas humanos, quando o sentido solidifica-se e se amplia como impasse, indecisão, perplexidade e problema. A questão crucial que se põe é a de ser, ou não ser, favorável à construção de um abrigo para recolher moradores de rua, naquela área específica.

Na primeira afirmativa, o modo está constituído por "Fernando Willian, secretário de ação social do Rio, está surpreso....”, com o sujeito identificado, e o predicador 'surpreso' a indicar afeto. Através desse adjetivo, que tem significado atitudinal ao expressar reação de baixa intensidade a um estímulo (desaprovação dos moradores de Jacarepaguá), é exposto o estado de espírito do secretário, pois ele não está desapontado nem enfurecido (que seria classificado, então, de média ou alta intensidade): está apenas surpreso. O resíduo "com alguns moradores da Praça Seca, em Jacarepaguá” apresenta adjunto conjuntivo numerativo que, generalista, não precisa o número de moradores contrários à medida, enquanto o adjunto modal identifique o lugar desses moradores (identificador).

$\mathrm{Na}$ afirmativa "[Alguns moradores] [são] contrários à construção de um asilo no lugar," tanto o sujeito quanto o finito estão elípticos e o predicador contém o critério avaliativo de julgamento, desde que tem a propriedade de indicar dado que pode levar os seus possuidores a serem elevados ou rebaixados pela sanção social. O complemento, pelo adjunto modal, define que a oposição à construção do abrigo é restrita àquele lugar, ou seja, a Praça Seca, em Jacarepaguá.

A opinião do secretário é marcada pela reprodução de um ato de fala:

- As pessoas querem que sejam construídos abrigos para recolher moradores de rua. Mas bem longe dela. 
O sujeito é identificado e o finito, no tempo presente, caracteriza a continuidade do pensamento dessas pessoas, desde que não é restrito a um fato do passado, com ideia de permanência, a significar uma modalização epistêmica. No resíduo, é encontrada uma formação de voz passiva com a omissão do agente, mas com identificador e adjunto modal indicando a finalidade do empreendimento: para recolher moradores de rua. A modalização "mas" dá entrada ao sujeito elíptico identificado (afetado) e ao presente e predicador subtendidos [os abrigos] [devem] [ficar]. No resíduo está outra modalização - bem - que introduz o critério de apreciação, a expressão a reação diante da possibilidade da existência de um abrigo nas cercanias, desde que somente cairiam bem se fossem edificados “bem longe delas.” Essa reação está ancorada numa avaliação constituída por afeto, que se transforma em julgamento, a partir inicialmente de itens de conveniência e estética.

Na última frase, entra a fala do jornalista/locutor, que deixa de narrar e expressa a sua incredulidade: "É. Pode ser". O sujeito da oração, apesar de gramaticalmente inexistente, reporta-se a um 'tudo isso que eu lhes contei:' apresenta uma modalização epistêmica, com a evidência do critério de julgamento como garantia da aceitabilidade social, desde que as normais de polidez exigem o respeito à opinião alheia. O identificador, com a forma subjacente, indica a possibilidade de que a história possa ser verdadeira.

Os verbos são empregados no presente do Indicativo, como registro de uma ação passada, o que se enquadra na categorização de Weinrich (1973) sobre a função dos tempos verbais para indicar atitude de locução, de tensão ou relaxamento e na divisão dos verbos em comentativos, quando o mundo comentado expressa, através do presente, passado e futuro, atitude de locução tensa, em verbos narrativos, representando ações definidas e sem grau de tensão, significando a exposição de atitude de narração relaxada. Para esse autor, o emprego dos tempos comentativos tem por objetivo fazer saber ao interlocutor que o texto merece de sua parte uma atenção diligente e concentrada. A maior parte dos textos jornalísticos é constituída por narrativas. Portanto, os 
jornalistas procuram contar histórias da vida real e cotidiana, feias ou bonitas, com um discurso organizado por regras, normas e convenções que caracterizam esse tipo de produção midiática.

Há ocorrência de um processo relacional atributivo circunstancial e, outro, relacional identificativo, processo mental e processos materiais. A polaridade predominante é a positiva. O destinatário da mensagem, o leitor, é deixado de lado, pois

não é usado nenhum recurso para uma formação dialógica hipotética.

Van Dijk (1990, p.112) continua atual ao considerar que o discurso jornalístico tem as limitações do texto escrito e impresso como monólogo e que os leitores, como participantes da comunicação, estão presentes somente de forma indireta, pois o que é escrito não se dirige especificamente a um receptor personalizado, a um sujeito identificado. A notícia jornalística é um discurso público cujas regras estilísticas permitem o distanciamento em relação "a um usual e implícito leitor"

Nos segmentos iniciais, existe o apagamento da voz do jornalista Alcelmo Gois: ele somente expõe a informação que recebeu, provavelmente da assessoria de imprensa do secretário Willian que, no entanto, fala por si mesmo ao assumir a autoria do enunciado. O cargo que ocupa expõe o processo de legitimação que pode ser visto como um dos meios para concretização, transmissão ou operação da ideologia. Na notícia em foco é apresentada a estratégia de racionalização que, segundo Thompson (2009, p.82), facilita ao produtor da forma simbólica a construção de "uma cadeia de raciocínio".

Soma-se a tal procedimento, a observância das regras próprias do gênero jornalístico, o que torna possível a compreensão, adequação e sequenciamento lógico dos fatos relatados, emprestando-lhes maior credibilidade, uma vez que há legitimidade na voz de quem narra e na de quem declara algo sobre o fato narrado: "O recurso a citações em discursos diretos torna mais fluída a narrativa, mais atraente o texto, mais leve a leitura e, sobretudo, mais credível o texto" (SOUSA, 2004, p. 86). Dessa forma, é apresentado ao leitor esse efeito de sentido de 
verdade, pois o redator é identificado, a coluna é assinada, o jornalista goza de credibilidade e, consequentemente, tem público considerável.

No fecho da notícia surge o enunciador em grande estilo. Ancelmo Gois assume o dito ao se materializar e se apresentar, dando o seu toque pessoal com uma forte carga de ironia, através da modalização expressiva, com manifestação de julgamento (Appraisal): "É. Pode ser." Observa-se que esse "eu” que, na sua produção textual, refere-se a um "ele" que é a pessoa que fala entre aspas, que diz, que assume proposições e posições e o "tu” que, nebuloso e anônimo, é a pessoa para quem o jornalista reporta o fato, como destinatário e receptor. Para fundamentar a informação jornalística, o colunista buscou o depoimento do homem público Fernando Willian, secretário do Rio de Janeiro, autoridade legalmente qualificada, portanto legitimada, a emitir juízo de valor e suposições factíveis.

E é assim que acontece o desenrolar do discurso jornalístico que, segundo Véron (2004. p.131), corresponde a uma descrição como se fosse um 'relatório' sobre os fatos; quando "o enunciador, definindo-se como 'jornalista' nunca ultrapassa os limites estabelecidos pela tarefa (do qual existe uma representação social).” Dessa forma, é que são apresentadas expressões que permitem a classificação (VAN LEEUWEN, 1999) de pessoas quanto à profissão e aos papéis sociais - através da legitimação, representada pela autorização em referência à autoridade ou tradição, costume, lei ou o papel institucional de alguém que o faz uma autoridade, de modo a asseverar a validade da informação e garantir a credibilidade.

$\mathrm{O}$ fato narrado é que o governo do Rio de Janeiro deve/precisa construir abrigo para moradores de rua. No entanto, esses moradores não são ouvidos, são apáticos e apagados do discurso; não são o foco da exposição, constituindo uma presença residual periférica. A notícia faz referência ao “secretário” que está “surpreso” com a ausência de aprovação dos habitantes do local escolhido pela Secretaria, nominalização do poder constituído como estratégia típica de construção simbólica, usando a reificação como modo de operação ideológica. A atitude de 
perplexidade da autoridade dá ensejo à pressuposição do jornalista Gois de que ele é "ingênuo," ou "deslocado da realidade," através da pista linguística fornecido com "É. Pode ser," quando o finito mais o predicador de "poder ser verdade" apontam para a existência de uma metáfora gramatical de modo.

\section{Considerações Finais}

Com a eliminação, ou ofuscação, do caráter sócio-histórico da existência das pessoas que vivem nas ruas, perde-se a oportunidade de proceder a análise do que representa para eles e para a sociedade esse modus vivendi. As notícias veiculadas pela imprensa tratam, muitas vezes, da morte desses indivíduos destituídos da sua cidadania, o que os aproxima de todos os outros cadáveres anônimos que os antecederam. Tal recurso funciona como escape que se furta à exposição de julgamento, que iria além da anunciação do desaparecimento de quem já era um ser desaparecido da cena social e econômica que, com a morte, atinge o ponto maior do anonimato próprio de uma vida apequenada, até o paroxismo de ter direito a "ser notícia no jornal” porque, enfim, pode ser notada, vez que estar morto prova existência de um ser anteriormente vivo.

Nas matérias jornalísticas são encontrados atos de fala, segundo a classificação de Habermas (1989), do tipo comunicativo, com a obediência às normas semânticas e sintáticas da língua; constatativo, pela utilização de frases com sentido cognitivo como pretensão de verdade; expressivo, quando o repórter apresenta-se ao leitor como autorizado a manifestar-se, ou destinar ao seu entrevistado espaço para dizer algo; e o regulativo, cuja disposição das frases estabelece uma relação mediada entre emissor e receptor, ou seja, repórter e leitor. É esse paradigma linguístico que fornece a dimensão política à linguagem, que se traduz no agir comunicativo.

Por sua vez, as observações de Foucault levam à constatação de que o discurso jornalístico evidencia a carga e a distribuição das relações 
que aproximam poder e saber: cabe à imprensa pesquisar, inquirir para, então, divulgar os fatos, buscando responder aos questionamentos e satisfazer as necessidades de informação dos leitores, sem perder o foco na legitimação do processo de produção da notícia, à qual está agregada a indispensável credibilidade, sempre escolhida como o maior valor agregado à determinada empresa jornalística.

A teoria da argumentação evidencia de que tal atividade deixa marcas linguísticas no enunciado; está inscrita na língua, pois são os próprios elementos lingüísticos que orientam a argumentação e não os fatos que podem ser representados pela língua (DUCROT, 1977). Dessa forma, a argumentação exerce uma função constitutiva no discurso, levando o interlocutor a uma determinada conclusão ou, até mesmo, a uma mudança de significado ou de posicionamento em relação a uma opinião.

Um dos pontos facilmente identificável no texto da mídia, impressa ou falada, é a argumentação como estratégia discursiva independentemente do subgênero jornalístico a que se refira. Na maioria das vezes, a utilização de argumentos apresenta um raciocínio lógico com elementos conceituais tão claramente dispostos que se traduzem, pela decodificação do receptor, na representação da verdade. Obviamente o que chega ao noticiário, mesmo o que é enviado pelo leitor, depende da prévia seleção dos editores, que passa pelo crivo do valor-notícia.

No caso dos moradores de rua, a classificação do valor-notícia é baixa. Explicações prováveis estão na conceituação de Pinto (2009, p. 60) sobre o que é notícia. Para ela, além de conter sempre uma novidade, é uma combinação de duas características indispensáveis que são a importância e o interesse: "Uma informação será tão mais forte - e atrairá mais o leitor - quanto mais dessas duas características tiver.” Baseada em manuais de jornalismo, lista critérios para identificar a importância de uma notícia que passa por ineditismo, utilidade, apelo, empatia, exposição de conflito, ou de proeminência, e pela oportunidade.

Os estudos de Bourdieu (1990) sobre o poder simbólico, mais especificamente o poder simbólico do campo do jornalismo, são esclarecedores quanto à questão. O poder simbólico surge como todo 
o poder que consegue impor significações como legítimas. Os símbolos afirmam-se, assim, como os instrumentos de integração social, tornando possível a reprodução da ordem estabelecida. O campo surge como uma configuração de relações socialmente distribuídas que levam à relação de sentido. O poder simbólico é um poder de fazer coisas com palavras. E somente na medida em que é verdadeira, isto é, adequada às coisas, que a descrição faz as coisas. Nesse sentido, o poder simbólico é um poder de consagração ou de revelação, um poder de consagrar ou de revelar coisas que já existem. (BOURDIEU, 1990, p. 167)

É assim que a ideologia produzida pelo emissor chega a ser facilmente incorporada pelo destinatário da mensagem, mesmo que não seja necessariamente explicitado o objetivo de persuadir, de influenciar o receptor com apelos à razão, emoção, a imaginação, a ser concretizado na transferência de um determinado ponto de vista, de uma opinião a partir da informação de um fato específico pretensamente veraz. A hierarquização lógica reflete no campo lexical ou semântico a prática discursiva do emissor que se consubstancia na escolha de determinadas palavras para ocupar certas posições sintáticas relacionando o eixo paradigmático com o eixo sintagmático. As escolhas lexicais refletem a posição do autor.

Uma das afirmativas da ADC pode ser constada em mensagens dos leitores no que se refere à importância da linguagem na vida social como resultante de um maior grau de intervenções intencionais e denotando várias dimensões sociocognitivas, tais como conhecimento, valores e crenças individuais socialmente compartilhadas. Parece, então, que tudo que é permitido, aprovado e comprovado pelo discurso jornalístico, pode, então, ser multiplicado através do discurso do leitor, que tenta adequar a sua linguagem à maneira do primeiro, embora carregue mais nas tintas, quando o pouco é velado e o muito é dito às claras. Há que se lembrar da visão de qualquer texto faz parte de uma cadeia de textos a manter relação de reação, incorporação e transformação em outros textos, a formar a "metáfora do mosaico de citações." (BAKTHIN, 1992). 
A pragmática é constatada pelo emprego da linguagem como realização de uma ação representada pela configuração de sentido resultante de uma prática social. Atos de fala são identificados no discurso jornalístico pelo desempenho do papel de mediação. Assim, o uso da linguagem é o meio para estabelecer um sentido comum e promover a indispensável coesão social, através de uma produção seqüenciada e com cunho de permanência. Embora sua ação tenha esse poder que se consolida através da credibilidade e da capacidade de informação, o jornalista não pode controlar a multiplicidade de sentidos que a sua mensagem possa suscitar.

Recebido em: outubro de 2009 Aprovado em: dezembro de 2009 tecafrazao@yahoo.com.br

\section{Referências Bibliográficas}

BAKHTIN, M. El marxismo y la filosofia del lenguaje. Madrid: Alianza: 1992. BENJAMIN, Walter. Imagination y Sociedade. Madrid: Taurus, s/d.

BOURDIEU, Pierre. O Poder Simbólico. Trad. F.Tomaz. Rio de Janeiro: Bertrand, 1989.

DUCROT, O. Dizer e não-dizer: princípios da semântica lingüística. Trad. Carlos Vogt. São Paulo: Cultrix, 1977.

Le dire et le dit. Paris: Minuit, 1984.

FAIRCLOUGH, Norman. Discurso e Mudança Social. Trad.de Isabel Magalhães. Brasília: Editora da Universidade de Brasília, 2001.

don: Routledege, 2003.

Analysing discourse: textual analysis for social research. Lon-

FOUCAULT, Michel A Arqueologia do Saber. Trad. L.F.B. Neves. Rio de Janeiro: Forense-Universitária, 1986.

HALL, S. The Work of Representation. In: Representation: cultural representations and signifying practices. London: Sage, 2000. 
HALLIDAY, Michael A. K. Introduction to Functional Grammar, 2a edição. London: Edward Arnold, 1994.

HABERMAS, Jüngen. Consciência Moral e Agir Comunicativo. Rio de Janeiro: Tempo Brasileiro. 1989.

MARTIN, J.R. Beyond Exchange: Appraisal Systems in English. In Evaluation in Text: Authorial Stance and the Construction of Discourse, edited by Hustan \&Thompson. UK: Oxford University Press, 2003.

MARTIN, J. R. e WHITE, P. R. R. The Language of Evaluation: appraisal in English. London: Palgrave/Macmillan, 2005.

MARTIN, J. R. e ROSE, D. Working with Discourse. London/New York: Continuum, 2002.

MARTIN, J. R. e ROSE, D. Genre Relations: Mapping Culture. London/New York: Equinox Published,London / Oakville 2008.

PARDO A, Neyla G. Discurso, Impunidad y Prensa. Bogotá: Universidad Nacional de Colômbia/Departamento de Lingüística, 2007.

SILVA, Denize Elena Garcia. A pobreza no contexto brasileiro: da exclusão econômica social à ruptura familiar. In: Revista multidisciplinar da Internet: Discurso \& Sociedad, 2 (2) 2008, 265-296.

SOUSA, Jorge Pedro. Introdução à Análise do Discurso Jornalístico Impresso. Florianópolis: Letras Contemporâneas, 2004.

THOMPSON, John. Ideologia e Cultura Moderna. Petrópolis: Vozes, 2009.

VAN DIJK. T. Discurso e Poder. São Paulo: Contexto, 2008.

Ideología y Discurso. Barcelona: Ariel: 2003.

La Noticia como Discurso. Barcelona: Paidós, 1990.

2000.

(compilador). El Discurso como Interacción Social. Barcelona: Gedisa,

VAN LEEUWEN. A Representação dos Actores Sociais. In: Pedro,Emília Ribeiro(org). Análise Crítica do Discurso. Lisboa: Caminho, 1997. (Coleção universitária, série lingüística).

VÉRON, Eliseo. Fragmentos de um tecido. São Leopoldo: Editora Unisinos, 2004.

WEINRICH, H. Les Temps. Paris: Éditions du Seuil: 1973.

WHITE, Peter. Valoração - a linguagem da avaliação e da perspectiva. Santa Catarina: Revista Linguagem em Discurso. Vol.4, número especial, Editora Unisul, 2004. 